\title{
Analysis of Lifestyle and Consumer Attitude Towards Intention to Purchase a Personal Car During Pandemic
}

\author{
Diana Marina $^{1}$, Nurmala K Pandjaitan ${ }^{2}$, Nur Hasanah ${ }^{3}$, Galih Putra Cesna ${ }^{4}$ \\ 1,2,3 IPB University, J1. Raya Dramaga Kampus IPB Dramaga Bogor 16680 West Java, Indonesia ${ }^{4}$ University \\ of Raharja, Modern, Jl. Jenderal Sudirman No.40, Cikokol, Kec.Tangerang, Kota Tangerang, Banten 15117 \\ ${ }^{1}$ diana63@apps.sb.ipb.ac.id, ${ }^{2}$ nurmala ${ }_{k}$ atrina@yahoo.co.id, ${ }^{3}$ nur.hasanah@apps.ipb.ac.id, ${ }^{4}$ galih.putra@ raharja.info
}

\begin{tabular}{l}
\hline \hline Article Info \\
\hline Article history: \\
Received 27-12-2021 \\
Revised 25-01-2022 \\
Accepted 01-12-2023
\end{tabular}

\section{Keywords:}

Covid-19

Pandemic

Economic

Vehicle

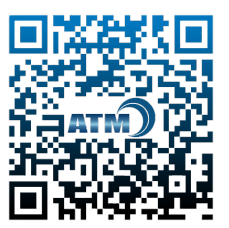

\begin{abstract}
The COVID-19 pandemic is a new virus that allegedly originated in Wuhan, China, in 2019. This COVID-19 has spread rapidly, disrupting all sectors of life in various countries. The Covid-19 pandemic also impacted Indonesia's economic decline in 2020 and triggered the acceleration of the world recession. The policy of Large-Scale Social Restrictions (PSBB) and regional quarantine significantly impacted the delay in the distribution of goods, which resulted in employee housing and even layoffs. The fear of contracting COVID-19 triggers the intensity of the use of private vehicles as well as the intention to own a car. Lifestyle changes in traveling, especially the choice of the private car, are also influenced by the primary destination and distance traveled during the pandemic. But the economic pressure of the impact of the pandemic has become a substantial perception control that holds back the realization of intention to make a personal vehicle purchase decision. Although there has been an increase in the frequency of private vehicle use during the pandemic, in reality, the increase has not impacted private car sales. This is caused by the purchasing power of consumers, who are still hampered because of the pandemic. The government itself is aware that the automotive industry is an industry that has a significant contribution to 20 percent of the national Gross Domestic Product (GDP) and absorbs 1.5 million workers. This prompted the government to issue a stimulus in the form of policy relaxation to boost the productivity of the auto industry.
\end{abstract}

This is an open access article under the CC BY-SA license.

\section{Corresponding Author:}

Galih Putra Cesna

University of Raharja, Tangerang, Indonesia

Email: galih.putra@raharja.info

\section{INTRODUCTION}

The COVID-19 pandemic is a new virus that allegedly originated in Wuhan, China, in 2019. This COVID-19 is spreading rapidly, disrupting all sectors of life in various countries. In Indonesia itself, the first confirmed case of COVID-19 was on March 2, 2020, and has been declared a national disaster [1]. The mass and massive transmission of COVID-19 forced the government to issue protocol policies such as masks, social services, and a flight ban. Guidelines make it easy to delay its spread, as suggested by [2] in their research on its implementation in China. The policy can reduce 90 percent of daily incidence will not exceed one infection per 1000 people. The infection prediction model developed by [3] developed the infection prediction model also reduces mobility, requires restrictions, and slows the virus.

The Covid-19 pandemic that has occurred since March 2020 in Indonesia has shifted people's behavior, including the travel lifestyle. Concerns about the transmission of the epidemic, the implementation of 
the Large-Scale Social Restriction (PSBB) policy, and the Enforcement of Community Activity Restrictions (PPKM) have increased people's intention to travel using private cars instead of public transportation.

The survey in the field said that the increasing intention of people to use private cars also increased people's choices to buy personal vehicles to facilitate mobility and reduce the risk of transmission while traveling. The need for private vehicle results from the threat of information and the type of work or the fulfillment of daily requirements for activities outside the home. However, the intention to own is not directly proportional to realizing new car sales in 2020. This is due to the economic pressure due to the pandemic, which has impacted the declining purchasing power of consumers.

The Covid-19 pandemic also impacted Indonesia's economic decline in 2020 and accelerated the world recession.[4] The Large-Scale Social Restriction (PSBB) policy and had a significant impact on the delay in the distribution of goods, which resulted in settlement of employees and even termination of employment (PHK). This increases the level of open partitions. This follows the results of the BPS survey [5], which resulted in changes in income and the number of employees in the company, as presented in Figure 1.
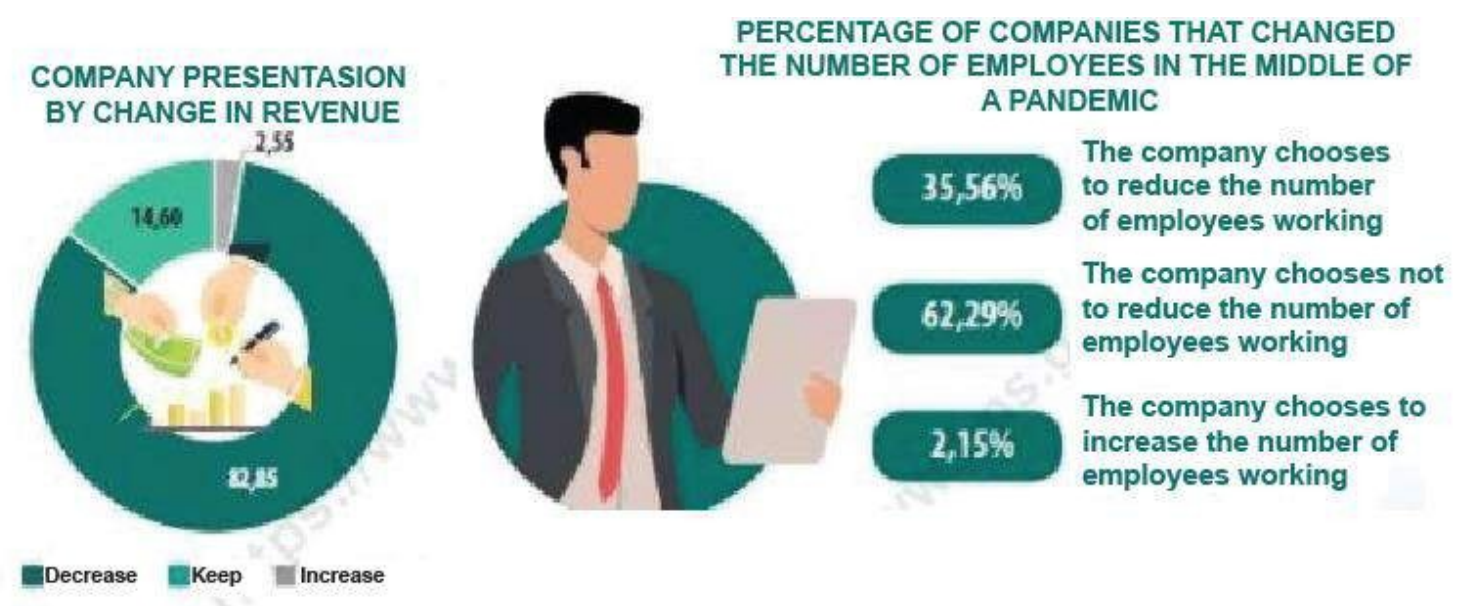

Figure 1. Changes in income and number of employees during the 2020 COVID-19 pandemic

Figure 1.1 explains that the impact of the pandemic on business actors is that 82.85 percent of companies tend to experience a decline in revenue. This causes the company to choose to reduce the number of employees working by 35.56 percent. The three business sectors most affected by COVID-19 are: Accommodation and food and drink by 92.47 percent, other services by 90.90 percent, and transportation and warehousing by 90.34 percent. The conditions caused by the current pandemic also impact public spending, namely 52.84 percent of respondents stated that they experienced an increase in spending compared to the beginning of the pandemic and PSBB [6].

The Covid-19 pandemic that has occurred since March 2020 in Indonesia has shifted people's behavior, including the travel lifestyle. Concerns about the transmission of the epidemic, the implementation of the Large-Scale Social Restriction (PSBB) policy, and the Enforcement of Community Activity Restrictions (PPKM) have increased people's intention to travel using private cars instead of public transportation.

The survey in the field said that the increasing intention of people to use private cars also increased people's choices to buy personal vehicles to facilitate mobility and reduce the risk of transmission while traveling. The need for private vehicle results from the threat of information and the type of work or the fulfillment of daily requirements for activities outside the home. However, the intention to own is not directly proportional to realizing new car sales in 2020. This is due to the economic pressure due to the pandemic, which has impacted the declining purchasing power of consumers.

The Covid-19 pandemic that has occurred since March 2020 in Indonesia has shifted people's behavior, including the travel lifestyle. Concerns about the transmission of the epidemic, the implementation of the Large-Scale Social Restriction (PSBB) policy, and the Enforcement of Community Activity Restrictions (PPKM) have increased people's intention to travel using private cars instead of public transportation.

The survey in the field said that the increasing intention of people to use private cars also increased people's choices to buy personal vehicles to facilitate mobility and reduce the risk of transmission while travel- 
ing. The need for private vehicle results from the threat of information and the type of work or the fulfillment of daily requirements for activities outside the home. However, the intention to own is not directly proportional to realizing new car sales in 2020. This is due to the economic pressure due to the pandemic, which has impacted the declining purchasing power of consumers. The COVID-19 pandemic has changed people's lifestyles, which is related to travel behavior[7], in their research on changes in people's traveling behavior during a pandemic in several countries, stated that there was a significant shift in the use of public transportation to private vehicles driven by the perception of the risk of transmission where most of the trips were used for daily shopping purposes [8]. analyzed changes in Istanbul people's traveling behavior and transportation modes in three phases of the pandemic from January to January. April 2021 states that the popularity of using private vehicles increases in phase 2, namely the phase of widespread and the risk of transmission. However, there was no change in the third phase, namely the travel tightening and social distancing policies. This study is in line with [9], where Australians prefer to use private vehicles for activities outside the home because the perception of cleanliness is better maintained than public transportation. [10] said that community travel activities in the Kelowna region, Canada, were more encouraged during the pandemic to fulfill their daily needs. Private vehicles were the preferred mode of transportation, mainly for long- distance travel.

A survey conducted by [11] through EY.com stated that $32 \%$ of respondents who do not have a personal vehicle are interested in buying within the next six months. Even $19 \%$ of respondents who already have a private vehicle intend to increase vehicle ownership due to this. from pandemics. These results are not much different from Inventure-Alvara. Indonesian respondents stated that $53.1 \%$ of respondents intended to buy a car within six months after the vaccine was produced.

\section{Used cars will be more in demand after the pandemic}

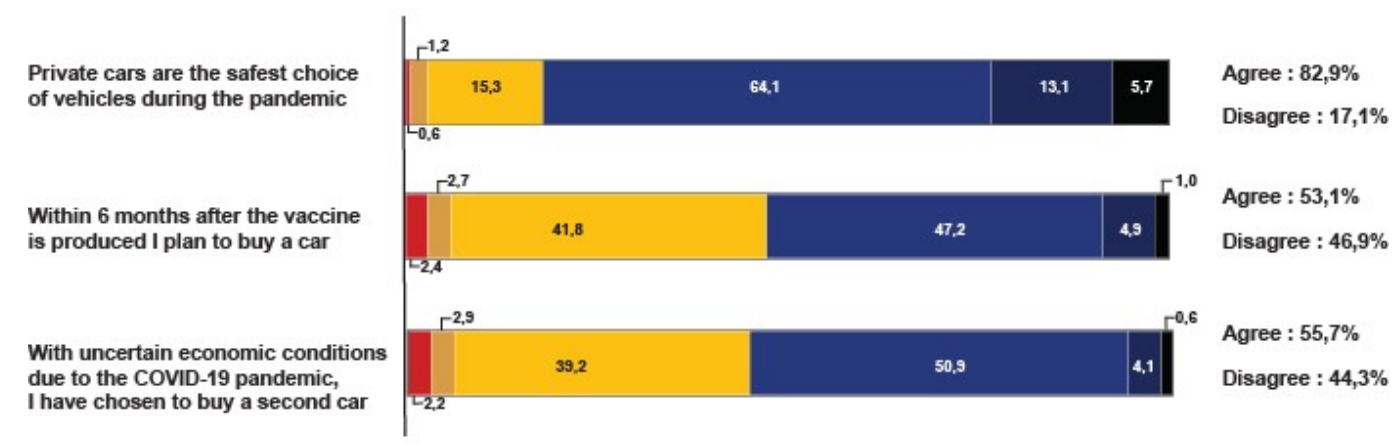

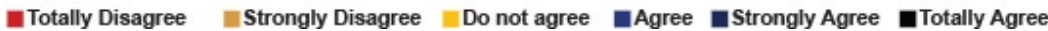

Figure 2. Survey of intention to buy a vehicle after the pandemic.

Although there has been an increase in the frequency of private vehicle use during the pandemic, in reality, the increase has not impacted private car sales. This is caused by the purchasing power of consumers, who are still hampered because of the pandemic. Data compiled from Gaikindo states that during 2020 there was a decline in four-wheeled automotive sales, both overall sales (wholesale) and retail sales. Overall sales decreased by 48.5 percent, while retail sales decreased by 44.7 percent, with sales contribution from Jabodetabek by $40 \%$.

The Covid-19 pandemic that has occurred since March 2020 in Indonesia has shifted people's behavior, including the travel lifestyle. Concerns about the transmission of the epidemic, the implementation of the Large-Scale Social Restriction (PSBB) policy, and the Enforcement of Community Activity Restrictions (PPKM) have increased people's intention to travel using private cars instead of public transportation.

The survey in the field said that the increasing intention of people to use private cars also increased people's choices to buy personal vehicles to facilitate mobility and reduce the risk of transmission while traveling. The need for private vehicle results from the threat of information and the type of work or the fulfillment of daily requirements for activities outside the home. However, the intention to own is not directly proportional to realizing new car sales in 2020. This is due to the economic pressure due to the pandemic, which has impacted the declining purchasing power of consumers. 
The Covid-19 pandemic that has occurred since March 2020 in Indonesia has shifted people's behavior, including the travel lifestyle. Concerns about the transmission of the epidemic, the implementation of the Large-Scale Social Restriction (PSBB) policy, and the Enforcement of Community Activity Restrictions (PPKM) have increased people's intention to travel using private cars instead of public transportation.

The survey in the field said that the increasing intention of people to use private cars also increased people's choices to buy personal vehicles to facilitate mobility and reduce the risk of transmission while traveling. The need for private vehicle results from the threat of information and the type of work or the fulfillment of daily requirements for activities outside the home. However, the intention to own is not directly proportional to realizing new car sales in 2020. This is due to the economic pressure due to the pandemic, which has impacted the declining purchasing power of consumers.

The government itself is aware that the automotive industry is an industry that has a significant contribution to 20 percent of the national Gross Domestic Product (GDP) and absorbs 1.5 million workers. This prompted the government to issue a stimulus in the form of policy relaxation to boost the productivity of the auto industry. The policy is in the form of relaxation of Sales Tax on Luxury Goods (PPnBM) which was inaugurated as of March 1, 2021.

In addition, to increase consumer purchasing power for the purchase of four-wheeled vehicles, especially private cars, the Bank Of Indonesia issued a policy of relaxing the imposition of advances for loans or purchases of motorized vehicles through PBI No.23/2/PBI/2021, dated February 26, 2021, which took effect from March 1, 2021, and a reduction in the lending facility interest rate to 4.25 percent BI. With the various drivers that the government has issued, it is hoped that a multiplier effect will be created that moves people to buy vehicles to boost economic growth in the recovery era of the COVID-19 pandemic. The automotive sector must be able to see the niche needs of consumers using private vehicles amidst economic pressures as a result of the impact of the pandemic.

From this explanation, it can be concluded that the government sees an excellent opportunity for national economic recovery through the automotive sector. The Indonesia International Motorshow (IIMS) Hybrid 2021, held in April, proved a niche market for consumers who intend to own a private vehicle during a pandemic despite depressed economic conditions. The visitors' car purchase intentions can be triggered by lifestyle, attitudes towards vehicle ownership, the encouragement of pandemic conditions, and government policy stimulus. This is as stated by [12]. Namely, the choice of transportation mode is influenced by lifestyle, which affects purchase intention [13].

The Covid-19 pandemic that has occurred since March 2020 in Indonesia has shifted people's behavior, including the travel lifestyle. Concerns about the transmission of the epidemic, the implementation of the Large-Scale Social Restriction (PSBB) policy, and the Enforcement of Community Activity Restrictions (PPKM) have increased people's intention to travel using private cars instead of public transportation.

The survey in the field said that the increasing intention of people to use private cars also increased people's choices to buy personal vehicles to facilitate mobility and reduce the risk of transmission while traveling. The need for private vehicle results from the threat of information and the type of work or the fulfillment of daily requirements for activities outside the home. However, the intention to own is not directly proportional to realizing new car sales in 2020. This is due to the economic pressure due to the pandemic, which has impacted the declining purchasing power of consumers.

The intention of private car ownership during the pandemic can be seen through consumers' attitudes in responding to private car ownership and the urgency of using private cars [14]. Behavior or intention to behave is influenced by attitudes towards behavior, subjective norms, and behavioral control. Therefore, further research is needed on buying a private car during the pandemic based on the Theory of Planned Behavior and consumer lifestyles.

\subsection{The scope of research}

The research will use quantitative methods using SEM-PLS analysis to analyze the effect of characteristics variables, travel lifestyle, attitudes towards private car ownership, subjective norms, and behavioral control based on TPB theory.

The object of this research is limited to the intention to purchase a private car during the pandemic in the Jabodetabek area. The selected respondents are consumers who have the will to buy a personal vehicle for the period April 2020 - August 2021. 
The Covid-19 pandemic that has occurred since March 2020 in Indonesia has shifted people's behavior, including the travel lifestyle. Concerns about the transmission of the epidemic, the implementation of the Large-Scale Social Restriction (PSBB) policy, and the Enforcement of Community Activity Restrictions (PPKM) have increased people's intention to travel using private cars instead of public transportation.

The survey in the field said that the increasing intention of people to use private cars also increased people's choices to buy personal vehicles to facilitate mobility and reduce the risk of transmission while traveling. The need for private vehicle results from the threat of information and the type of work or the fulfillment of daily requirements for activities outside the home. However, the intention to own is not directly proportional to realizing new car sales in 2020. This is due to the economic pressure due to the pandemic, which has impacted the declining purchasing power of consumers.

\section{RESEARCH METHOD}

\subsection{Time and Place of Research}

The research was conducted in the Greater Jakarta area from August to October 2021. Selection of Jabodetabek area based on information that sales of private vehicles in the Jabodetabek area support 30\%-40\% of vehicle sales throughout Indonesia.

\subsection{Research Approach}

This study uses quantitative methods [15]. States that a quantitative method is a scientific approach that views a reality that can be classified, concrete, observable and measurable. The relationship between variables is causal where the research data are numbers, and the analysis uses statistics. The research design used a cross-sectional research method. The researcher did not maintain research subjects that had to be observed for a long time but gave rise to new subjects who replaced old subjects from various age groups [16].

\subsection{Data collection}

The data used in this study are primary data and secondary data. Primary data was obtained through the distribution of online questionnaires. The online questionnaire was created using a Google Form distributed through the WhatsApp application. At the same time, the secondary data in this study was obtained through a literature study through references from books, journals, theses, dissertations, and information from internal vehicle dealers and other documents that support this research.

\subsection{Population and Research Sample}

The population in this study were exhibition visitors and vehicle dealers, both offline visits in the Greater Jakarta area for the period April 2020 - October 2021 and accessing the web for buying and selling vehicles during that period. The purposive sampling technique determined the number of samples in this study. Purposive sampling is a sampling technique with specific considerations [17].

The consideration taken in this study is the activeness of respondents in seeking information regarding purchasing a private car. The screening of respondents, namely: aged 18 years and over, domiciled in the Jabodetabek area and visited dealers or accessed the web for buying and selling vehicles in the period April 2020-September 2021.

The research sample size [18], the minimum number of samples required is five times more than the number of variables to be analyzed, and the acceptable sample size will have a ratio of 10:1. Researchers generally will use a limit of 50 samples as a minimum and preferably a sample size above 100 . Therefore the sample used is 100 . To anticipate data loss of more than $20 \%$, the data to be taken is at least 120 .

The Covid-19 pandemic that has occurred since March 2020 in Indonesia has shifted people's behavior, including the travel lifestyle. Concerns about the transmission of the epidemic, the implementation of the Large-Scale Social Restriction (PSBB) policy, and the Enforcement of Community Activity Restrictions (PPKM) have increased people's intention to travel using private cars instead of public transportation.

The survey in the field said that the increasing intention of people to use private cars also increased people's choices to buy personal vehicles to facilitate mobility and reduce the risk of transmission while traveling. The need for private vehicle results from the threat of information and the type of work or the fulfillment of daily requirements for activities outside the home. However, the intention to own is not directly proportional to realizing new car sales in 2020. This is due to the economic pressure due to the pandemic, which has impacted the declining purchasing power of consumers. 


\subsection{Variables, Indicators, and Operational Definitions of Research}

Most of the theories and models of social and behavioral sciences are measured directly in theoretical concepts or constructs [19]. The construct variable cannot be directly entered into the regression equation. Therefore, a structural equation is used that can overcome the use of these latent variables (unusable variables). Latent variables can be classified into exogenous and endogenous variables. Exogenous variables are independent variables that affect the dependent variable. In the SEM model, exogenous variables are indicated by arrows coming from these variables to endogenous variables. Meanwhile, the endogenous variable is the dependent variable influenced by the independent variable (exogenous). In the SEM model, exogenous variables are indicated by arrows leading to these variables.

Table 1. Latent variables of the matrix model

\begin{tabular}{|l|l|l|l|l|}
\hline Name & Description & Symbol & Element & Notation \\
\hline Variable & \multicolumn{4}{|l|}{} \\
\hline Eta & Variabel laten endogenous & $\mathrm{C}$ & $\mathrm{mxl}$ & \\
\hline $\mathrm{Xi}$ & Variabel laten eksogenous & $\xi$ & $\mathrm{nxl}$ & $\xi$ \\
\hline Zeta & Error Laten & $\xi$ & $\mathrm{mxl}$ & $\xi$ \\
\hline Model Variabel & Laten & \multicolumn{3}{|l|}{} \\
\hline Beta & $\begin{array}{l}\text { The influence between endogenous } \\
\text { latent constructs }\end{array}$ & $\beta$ & $\beta \mathrm{nn}$ & $\mathrm{BE}$ \\
\hline Gamma & $\begin{array}{l}\text { The influence between exogenous and } \\
\text { endogenous latent constructs }\end{array}$ & $\gamma$ & $\gamma \mathrm{nm}$ & $\mathrm{GA}$ \\
\hline Phi & $\begin{array}{l}\text { Correlation between exogenous } \\
\text { constructs }\end{array}$ & $\phi$ & $\phi \mathrm{mm}$ & PH \\
\hline Psi & $\begin{array}{l}\text { Correlation between endogenous } \\
\text { constructs }\end{array}$ & $\psi$ & $\psi \mathrm{nn}$ & PS \\
\hline
\end{tabular}

This study consists of three exogenous (independent) variables: lifestyle, attitudes towards private car ownership, subjective norms, and perceptions of control over private car ownership. Meanwhile, this study's endogenous (dependent) variable is the intention to purchase a private car. The Covid-19 pandemic that has occurred since March 2020 in Indonesia has shifted people's behavior, including the travel lifestyle. Concerns about the transmission of the epidemic, the implementation of the Large-Scale Social Restriction (PSBB) policy, and the Enforcement of Community Activity Restrictions (PPKM) have increased people's intention to travel using private cars instead of public transportation. The survey in the field said that the increasing intention of people to use private cars also increased people's choices to buy personal vehicles to facilitate mobility and reduce the risk of transmission while traveling. The need for private vehicle results from the threat of information and the type of work or the fulfillment of daily requirements for activities outside the home. However, the intention to own is not directly proportional to realizing new car sales in 2020. This is due to the economic pressure due to the pandemic, which has impacted the declining purchasing power of consumers. The variables, operational definitions, dimensions, and indicators in this study are as presented in Table 3.1. 


\begin{tabular}{|c|c|c|c|}
\hline No & Variable & Definition Variabel & Indicator \\
\hline 1 & $\begin{array}{l}\text { Characteristics } \\
\text { of Respondent } \\
\text { Identity }\end{array}$ & Subject of research & $\begin{array}{l}\text { Gender Income } \\
\text { Level Type of Work }\end{array}$ \\
\hline 2 & Lifestyle & $\begin{array}{l}\text { Lifestyle and individual } \\
\text { behavior orientation } \\
\text { towards the use of money and time }\end{array}$ & Interest Activities \\
\hline 3 & $\begin{array}{l}\text { Attitude towards } \\
\text { private car } \\
\text { ownership }\end{array}$ & $\begin{array}{l}\text { A person's belief in owning } \\
\text { a private car during a pandemic is based } \\
\text { on bothcognitive and affective }\end{array}$ & $\begin{array}{l}\text { Affective Cognitive } \\
\text { Opinion }\end{array}$ \\
\hline 4 & $\begin{array}{l}\text { Subjective } \\
\text { Norm }\end{array}$ & $\begin{array}{l}\text { Individual's perception of how } \\
\text { other people expect him to have } \\
\text { a private car so that it tries to be realized }\end{array}$ & Family \\
\hline 5 & $\begin{array}{l}\text { Control } \\
\text { perception }\end{array}$ & $\begin{array}{l}\text { The perception of control over } \\
\text { behavior is based } \\
\text { on the belief that management } \\
\text { is accessible and related } \\
\text { to factors that can facilitate } \\
\text { or hinder behavioral performance. }\end{array}$ & $\begin{array}{l}\text { Position / } \\
\text { Company Friends / } \\
\text { Community } \\
\text { Financial Ability }\end{array}$ \\
\hline 6 & Interest in buying a car & $\begin{array}{l}\text { Consumer preferences } \\
\text { to buy products }\end{array}$ & Treat Ability \\
\hline
\end{tabular}

\subsection{Data Processing and Analysis Techniques}

The data obtained will be processed and analyzed using validity tests to determine the extent to which the data collected can measure construct variables and test reliability to test the reliability of the data that has been obtained. To support the automotive industry in classifying potential consumers during the pandemic, factors in lifestyle variables and attitudes towards car ownership will be extracted first, and then grouped will be carried out. The steps for data processing and analysis are as follows:

- Descriptive analysis to analyze the description of the characteristics of the respondents.

- Structural Equation Modeling (SEM) analysis with the aim of

- Explores the structural relationship of lifestyle factors, attitudes, subjective norms, and perceptual control and extracts several aspects from the statements.

- Estimates the coefficients between lifestyle factors, character, attitudes, subjective norms, and perceived control which will affect purchasing a private car during the pandemic.

This study uses a Likert scale to determine the types of statements made on the questionnaire. The Likert Scale measures attitudes, opinions, and perceptions of a person or group of people about social phenomena. With a Likert scale, the measured variables are translated into variable indicators. Then the indicator is used as a starting point for compiling instrument items in the form of statements or questions. In this study, each respondent's answer to the questionnaire was given a weighted score of 1 to 5 based on the rating scale, then processed using Microsoft Excel software. Each scale represents a description from very negative to very positive, with the choices: Strongly agree (SS): 5, Agree (S): 4, Moderately agree (CS): 3 Disagree (S): 2 Strongly disagree (STS): 1. The following is an explanation of data processing and analysis.

\subsubsection{Validity and Reliability Testing}

Validity testing is carried out on the questionnaire that has been built to see how far the data that is accommodated in a questionnaire can measure what you want to measure. Validity shows the level or degree of evidence supporting conclusions drawn from scores derived from what size or scale should be measured. Validity testing aims to determine whether each of the variables asked can be used as a measuring tool. The validity test in this study was carried out using the Statistical Product and Service Solution (SPSS) software. The validity of an attribute can be seen in the SPSS output results in a table entitled Item-Total Statistics. A 
feature can be valid or not, and it can be seen from the corrected item-total correlation value. The research results are said to be helpful if the corrected item-total correlation is more significant than the $\mathrm{r}$ table (r-count $i$ r-table) or p-value ${ }_{i} 0.05$ [20] Invalid attributes must be removed or not asked respondents when collecting data in research.

The Covid-19 pandemic that has occurred since March 2020 in Indonesia has shifted people's behavior, including the travel lifestyle. Concerns about the transmission of the epidemic, the implementation of the Large-Scale Social Restriction (PSBB) policy, and the Enforcement of Community Activity Restrictions (PPKM) have increased people's intention to travel using private cars instead of public transportation.

A reliability test is a reliability test that aims to determine how far a tool can be trusted and consistent if measurements are repeated on different samples. A reliability test is used to measure that the variables used are entirely free from error. An instrument is reliable if a person's answer to the statement is consistent or stable from time to time to produce data similarity at different times. The measurement technique used is the Alpha-Cronbach technique because the scale used is a Likert scale. The reliability test in this study used SPSS software. The reliability of a variable (attribute) can be seen in the SPSS output results in the reliability coefficients table. The indicators of the reliability of the details can be seen in Table 2 .

\begin{tabular}{|l|c|l|}
\hline No & Indicator & \multicolumn{1}{c|}{ Criteria } \\
\hline 1 & Alpha $0,00-0,20$ & Unreliable \\
\hline 2 & Alpha $0,21-0,50$ & Less Reliable \\
\hline 3 & Alpha $0,51-0,60$ & Reliable enough \\
\hline 4 & Alpha $0,61-0,80$ & Reliable \\
\hline 5 & Alpha $0,81-1,00$ & Very Reliable \\
\hline
\end{tabular}

\subsubsection{Descriptive Analysis}

Descriptive analysis is used to describe the characteristics of respondents based on age, gender, study program categories. To analyze the features of the respondents, the data obtained were tabulated with Microsoft Excel and SPSS programs. Descriptive analysis was carried out by presenting data, using regular tables and frequency distributions; line and bar graphs; salted circle; pictograms; group explanation through mode, median, mean, and group variation through the range and standard deviation [21] This study will use a proportion assessment with the method (Mo) value based on the Likert scale answers.

\subsubsection{Structural Equation Model (SEM) Analysis}

SEM is a multivariate statistical analysis technique to test the existence of a complex direct or indirect influence, either unidirectional or not, to produce a comprehensive picture of the model. SEM with the PLS approach has high flexibility for researchers to connect theory with data [22]. SEM-PLS in this study was used to analyze the direct influence of each variable on purchasing a private car. In this study, descriptive analysis was used to analyze the description of the characteristics of the respondents.

In processing respondent data in this study using quantitative analysis using the SEM analysis method using variance-based SEM approach in the form of Partial Least Square (PLS). The purpose of using PLS-SEM is to test the predictive relationship between constructs by seeing whether there is a relationship or influence between these constructs [23] The PLS approach has higher flexibility for researchers in linking theory to research data. The application used to process the data is SmartPLS 3.0. The analysis process using SEM-PLS goes through three stages, namely the evaluation analysis of the measurement model (outer model), structural model evaluation analysis (inner model), and hypothesis testing with the following explanation:

- Measurement model evaluation analysis (outer model) There are two types of models in the outer model, namely the formative indicator model and the reflective indicator model. The constructive model assumes that the indicator affects the latent variable, while the reflective model assumes that the latent variable influences the needle. This study uses a reflective model assuming that latent variables influence indicators. In general, the measurement model analysis is carried out to assess the relationship between latent variables and their hands. The study of the outer model includes checking the convergent validity and discriminant validity. 
Convergent validity is divided into three measurements: individual item reliability, construct reliability, and average Variance extracted [24]. Particular item reliability can be analyzed by looking at the value of the loading factor with the condition that the loading factor $i 0.5$ is said to be ideal, meaning that the indicator is valid for measuring the construct it forms. Construct Reliability (CR) is used to measure the reliability of a construct with a limit value of 0.7 acceptable. Average Variance Extracted (AVE) describes the amount of Variance or diversity of manifest variables owned by the latent construct. The AVE value is said to be valid if $\mathrm{AVE}_{i} 0.5$ so that the variable is considered to explain the average of more than half the Variance of the indicator. Meanwhile, discriminant validity can be analyzed in two stages: looking at the cross- loading value of each hand in a latent construct with a correlation higher than 0.7 in the correlation of other latent constructs and comparing the correlation value of the latent variable with the AVE root value.

- Structural model evaluation analysis (inner model) The structural model analysis is an analysis that describes the relationship between latent variables in a research model. There are several things to consider in the structural model evaluation process, including the path coefficient to see the strength of the relationship between constructs. The results of the t-test or critical ratio (CR) from the bootstrapping process to know the significance of the relationship between constructs evaluate the value of R2 (R-square) with the criteria of $0.67,0.33$, and 0.19 as substantial, moderate (moderate), and weak. (weak). The next thing to note is the Goodness of Fit (GOF), which validates the combined performance of the measurement model and the structural model and Q2 predictive relevance to validate the model. 


\subsection{Research Model Design}

The design of the research model used can be seen in Figure 3. The figure shows the relationship between lifestyle variables consisting of activity, interest, and opinion indicators. The attitude variable towards car ownership is established through cognitive and practical hands. The subjective norm variable is shown through 3 needles, and the perception control variable is demonstrated through the ability and ability to maintain a car. Meanwhile, the intention to purchase a private vehicle is described through indicators of the plan to buy a car during a pandemic, in the last year, or after the pandemic is over.

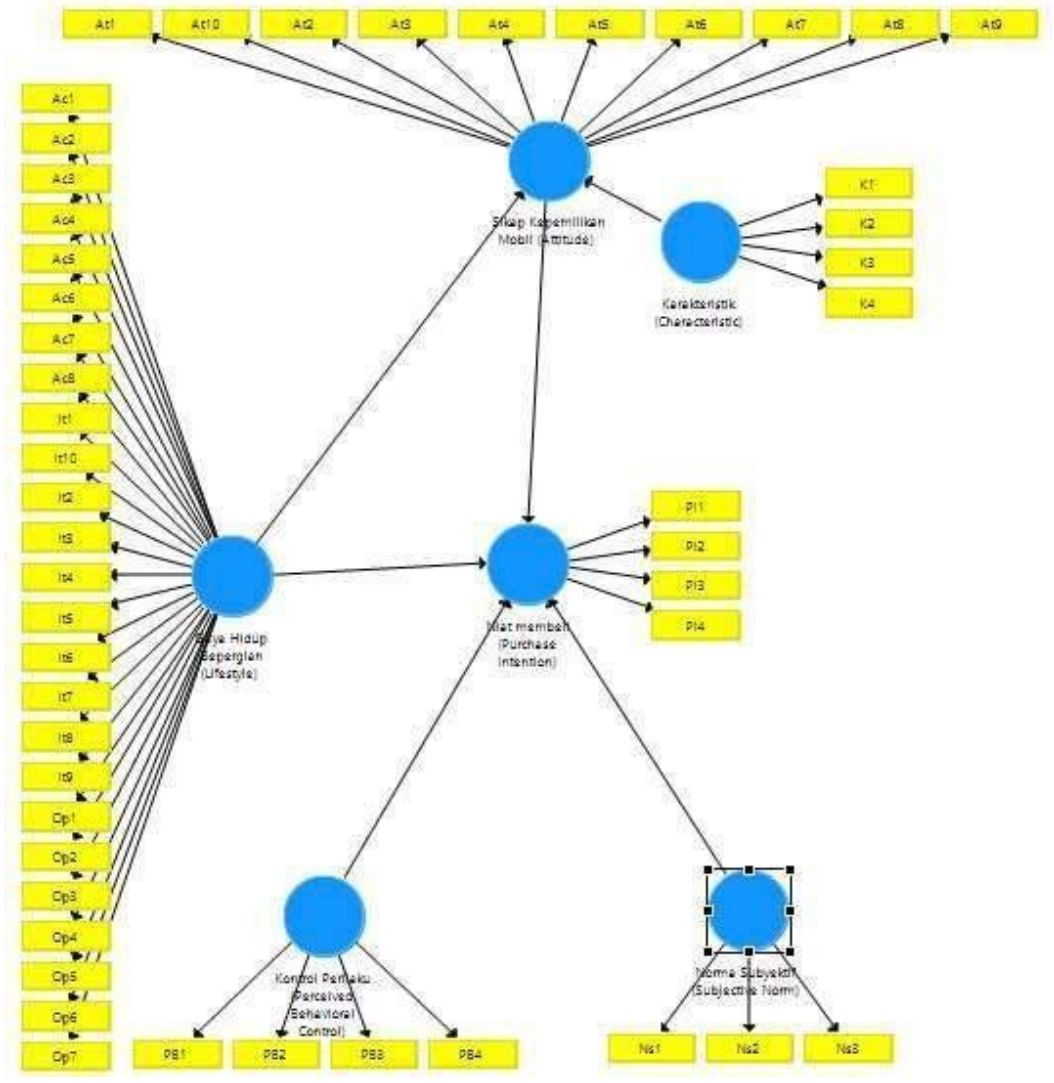

Figure 3. Research Model Design.

\subsection{Literature Review}

\subsubsection{Consumer behavior}

Humans cannot be separated from the process of consuming a product, either in the form of goods or services. The consumption process starts from the stages of identifying needs, analyzing, comparing, making decisions, and evaluating consumption results. Of course, in every step of consumption, many factors influence the process, both internal and external.

All stages and factors involved in the consumption process can be called consumer behavior. Translate consumer behavior as the study of the purchase of goods and the exchange process in obtaining, consuming, and disposing of goods, services, experiences, and ideas. Mowen emphasizes consumer behavior in exchanging resources that occur between companies and consumers.If [25] and [26]define consumer behavior as a consumer process in consuming a product, then [27] translates consumer behavior as consumer search and identity through the consumption process. [28] cites a definition from The American Marketing Association that consumer behavior includes thoughts and feelings from a person's experience and actions they take in consuming. The process is so dynamic that it involves interaction and exchange. Meanwhile, [29] states that consumer behavior is all activities, actions, and psychological processes that encourage these actions before buying, using, spending products and services after doing the things above or evaluating activities.

Studying consumer behavior will lead us to understand the consumer journey in consuming a product. 
[30] Stated that the purpose of studying consumer behavior is to know how and why consumers make decisions based on influencing factors versus facts and rationality and how marketers can effectively target consumer markets. Consumer behavior research consists of three perspectives, namely:

- The decision-making perspective (The decision-making perspective). This perspective assumes that consumers have a problem and carry out a rational decision-making process to solve the problem.

- The experiential perspective. The decision-making process is not always based on rational thinking but instead on excitement, fantasy, or the fulfillment of desired emotions.

- The behavioral influence perspective. The decision-making process is influenced by internal factors (cognitive and affective) and external factors such as marketing, culture, environment, economy, and laws.

The consumer behavior model is determined by the dimensions of psychology, sociology, anthropology, and communication through the stages of input, process, and output. Meanwhile explain the consumer behavior model in the following figure:

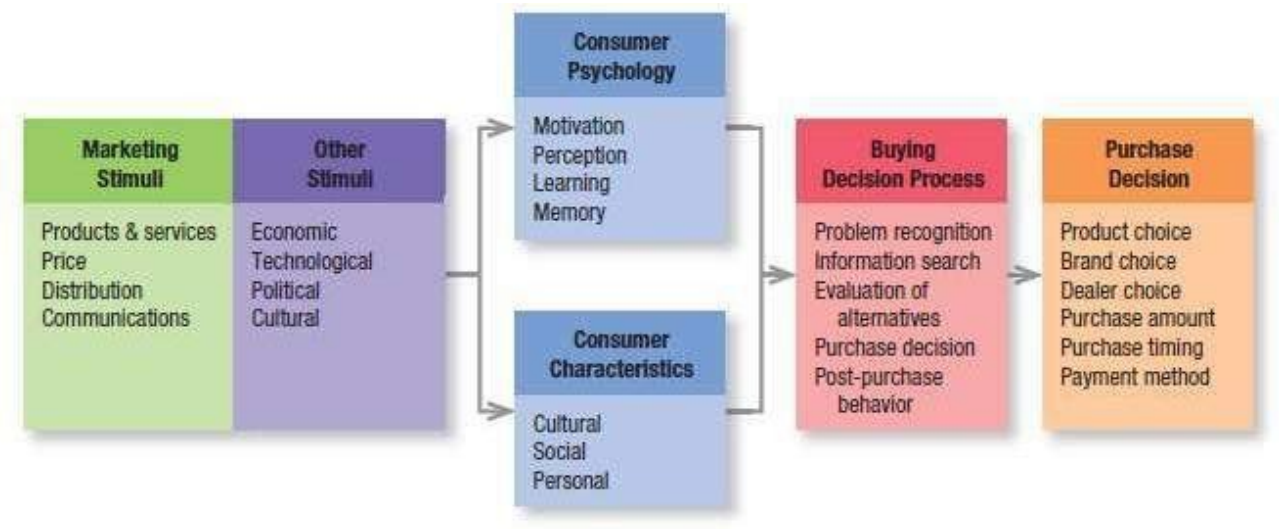

Figure 4. Consumer Behavior Model

\subsubsection{Travel Lifestyle}

Lifestyle is classified into personal factors, sociocultural influences, or intermediary factors between internal and external. Argues that lifestyle has two meanings: a lifestyle in using money and time and value and behavior orientation. Lifestyle as to how a person lives, characterized by how they live, spend money, and use their free time. lifestyle as a lifestyle expressed in activities, interests, and opinions. Kotler, lifestyle is partly shaped by the constraints of time or money experienced by consumers. Lifestyle is a pattern in which people live using money and time. in his research describes approaches that can be used to measure the concept of lifestyle, namely:

- Cultural lifestyle approach. Studying a lifestyle based on prevailing social norms and values.

- Sociographic lifestyle approach. Studying lifestyles with the aim of monitoring changes and trends in society by analyzing changes in shared individual opinions and attitudes.

- Psychographic lifestyle approach. Studying lifestyle of behavior by combining socio- demography, personality traits, norms, values, and attitudes.

- Mechanical lifestyle approach. Studying behavior patterns and the consequences of these behaviors can be seen from two dimensions, namely the social position space (which is determined by sociodemographics) and the lifestyle space (which is determined by behavioral patterns).

- Post-structural lifestyle approach. This lifestyle approach does not consider the emerging hierarchies among lifestyle groups. Lifestyle is seen as an individual choice that depends on local and temporal contexts. 
- Geographic lifestyle approach. The geographic (or geo-demographic) lifestyle approach combines various types of information about individuals with spatial data on their location (e.g., type of residence, environmental characteristics).

Psychographics is often interpreted as a lifestyle measurement based on AIO (Activity, Interest, Opinion) statements, namely the size of consumer activities, intentions, and opinions. Activity is a manifestation of action (work, hobbies, social, events, holidays, entertainment, community, shopping, sports, etc. Interest is interested in particular objects or topics such as family, home, work, community, recreation, fashion, food, media, achievements, etc. Lastly, opinion is a descriptive belief (towards oneself, social issues, politics, business, economy, education, products, future, culture, and so on). The fear of contracting COVID-19 triggers the intensity of the use of private vehicles as well as the intention to own a vehicle. Lifestyle changes in traveling, especially the choice of a private car, are also influenced by the primary destination and distance traveled during the pandemic. However, the economic pressure of the impact of the pandemic has become a firm perception control that holds back the realization of intention to make a personal vehicle purchase decision. A survey conducted by Ipsos, China's success in recovering new vehicle sales was driven by four factors: economic recovery, perceptions of security in using private vehicles, the desire to travel, and stimulus from the government. Intention to purchase a private car is also strongly influenced by attitude factors based on the Theory of Planned Behavior, followed by behavioral control and subjective norms. Meanwhile, The travel lifestyle has a close relationship with the level of car ownership.

\begin{tabular}{|c|c|c|c|}
\hline Activity & Intention & opinion & Demographics \\
\hline Work & Family & Self & Age \\
\hline Hobby & House & Social Issues & Education \\
\hline Social activities & Profession & Political & Income \\
\hline Holiday & Public & Business & Work \\
\hline Entertainment & Recreation & Economy & Big family \\
\hline Club Member & Mode & Education & House type \\
\hline Public & Food & Product & Geography \\
\hline Shopping & Media & Future & Big city \\
\hline Sport & Success & Culture & Life cycle \\
\hline
\end{tabular}

Table 2. Examples of Lifestyle (AIO) on Psychographic Measurements

The use of lifestyle to observe travel patterns and their impact on transportation modes was first investigated. Salomon said that lifestyle is an observable pattern of behavior but at the same time an orientation that underlies behavior so that the design of daily traveling behavior can explain a person's lifestyle. Traveling in a private vehicle is not simply a calculation of the costs and benefits but an indication of the value contained in the act of driving.

Research conducted states that lifestyle plays a significant role in purchasing a private car. The same thing was conveyed, which indicated that lifestyle positively affected purchase intentions and decisions. The research concluded that the attitude of car ownership has a close relationship with an active lifestyle outside the home.

\subsubsection{Theory of Planned Behavior}

A person who has belief in a particular behavior will not necessarily behave under his assumptions when faced with certain events. This is what underlies the theory of planned behavior presente. Specific ideas that stand out will encourage a person's actual behavior. These beliefs can be divided into behavior beliefs, normative beliefs, and control beliefs. Behavioral beliefs (behavior beliefs) produce favorable or unfavorable attitudes towards the behavior; normative beliefs have perceived social pressure or subjective norms, and control beliefs lead to perceived behavioral control or self-efficacy. The correlation between these beliefs and intentions as behavioral antecedents can be explained in the following figure. 


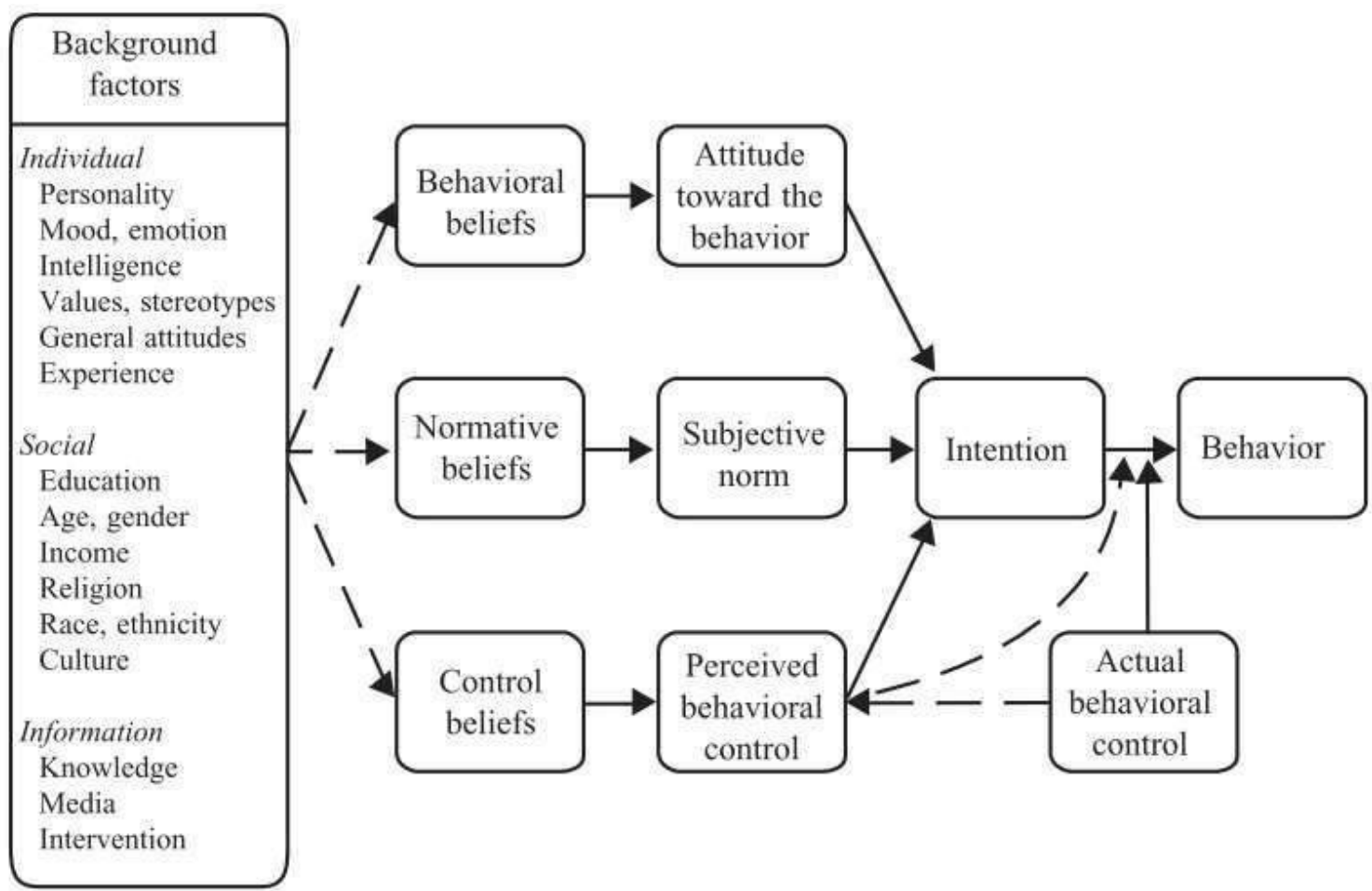

Figure 5. Schematic Representation of TPB

The theory of planned behavior (TPB) is a theory that uses intention as the closest predictive tool to predict someone's behavior. In the TPB model, the main factor influencing a person's behavior is his intention or tendency to take action. The intention will be affected by the main involved factors, namely attitudes towards behavior, subjective norms, and behavioral control.

\subsubsection{Attitude to behavior}

The concept of attitude plays an important position in psychology and consumer behavior. Research related to attitudes towards behavior discusses the belief and evaluation factors of attitudes that encourage consumers to behave. attitude is an expression of consumer feelings about an object, whether it is liked or not. Attitudes can also describe consumer confidence in various attributes and benefits of the object. attitude as a learned tendency to behave in a consistently favorable or unfavorable way concerning a particular thing. attitude is an evaluation of liking or disliking, emotional feelings, and a person's tendency to act towards an object or idea. From the definition of the attitude of some experts, the attitude can be concluded as a person's expression about an object or idea obtained from the learning process and overall evaluation.

The fear of contracting COVID-19 triggers the intensity of the use of private vehicles as well as the intention to own a vehicle. Lifestyle changes in traveling, especially the choice of a private car, are also influenced by the primary destination and distance traveled during the pandemic. However, the economic pressure of the impact of the pandemic has become a firm perception control that holds back the realization of intention to make a personal vehicle purchase decision. Asurvey conducted by Ipsos, China's success in recovering new vehicle sales was driven by four factors: economic recovery, perceptions of security in using private vehicles, the desire to travel, and stimulus from the government. Intention to purchase a private car is also strongly influenced by attitude factors based on the Theory of Planned Behavior, followed by behavioral control and subjective norms.Meanwhile, The travel lifestyle has a close relationship with the level of car ownership.

Evaluation is a person's affective response (usually at a relatively low level of intensity and arousal) created through the cognitive and affective systems. Despite much debate regarding the dimensions of attitude, most researchers accept mental (knowledge), affective (emotions, feelings), and behavior (tendency to act) as components of philosophy. In this case, attitudes are measured using cognitive and affective dimensions, the cognitive and affective dimensions of perspectives simultaneously explain behavioral intentions. 


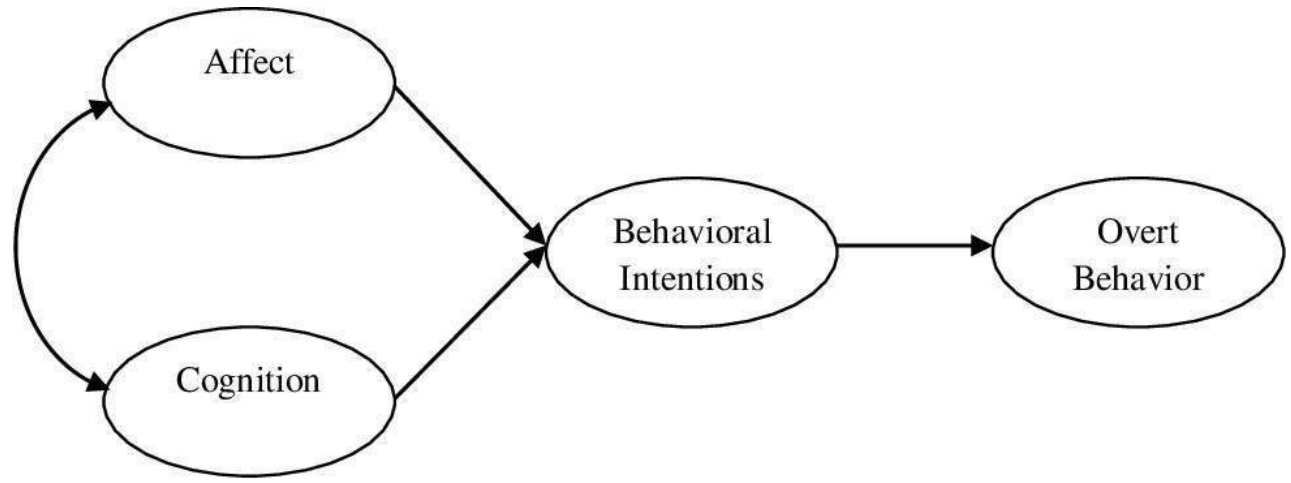

Figure 6. Attitude components and manifestations

General attitudes toward physical objects, institutions, ethnic or religious groups, and so on are good predictors of behavioral patterns or multiple action criteria, and that attitudes toward behavior are good predictors of single actions. Although attitudes can change, which is influenced by situational factors, attitudes and behavior involve elements of effort, purpose, context, and time explicitly translated. Intention to buy a private car is closely related to attitudes towards vehicle ownership, in research on the intent to purchase a safer car in Indonesia, stated that attitude is the most substantial influencing factor, followed by behavioral control and subjective norms. In their research, individuals who seek status, are image-conscious, passionate about cars, obsessed with cars, and influenced by peers will be more likely to buy cars shortly. The car is a symbol of self in affection that affects the attitude of car ownership conveys that people who have a materialistic value orientation are more likely to perceive expensive cars as a symbol of status and success.

The fear of contracting COVID-19 triggers the intensity of the use of private vehicles as well as the intention to own a vehicle. Lifestyle changes in traveling, especially the choice of a private car, are also influenced by the primary destination and distance traveled during the pandemic. However, the economic pressure of the impact of the pandemic has become a firm perception control that holds back the realization of intention to make a personal vehicle purchase decision. Asurvey conducted by Ipsos, China's success in recovering new vehicle sales was driven by four factors: economic recovery, perceptions of security in using private vehicles, the desire to travel, and stimulus from the government. Intention to purchase a private car is also strongly influenced by attitude factors based on the Theory of Planned Behavior, followed by behavioral control and subjective norms.Meanwhile, The travel lifestyle has a close relationship with the level of car ownership.

\subsubsection{Subjective Norm (Subjective Norm)}

The purchase of a car is not only influenced by internal factors but also by external factors. The opinionsof others from the reference group can motivate a person to fulfill that opinion. This is referred to as the subjective norm. Subjective norm is translated as perceived social pressure to perform or not to perform a behavior. The subjective norm is an individual's perception of how other people expect him to behave and motivation to fulfill different essential expectations. Measuring subjective norms, researchers can use two types of means to get a complete picture, namely: injunctive (perceptions of what other people think should be done) and descriptive (perceptions of what other people do). Other). This descriptive norm has shown its influence on the choice of transportation modes, either directly or indirectly

\subsubsection{Perception of Control on Behavior}

The perception of control over behavior is basedon the belief that management is accessible and related to factors that can facilitate or hinder behavioral performance. the construction of perceived control can be divided into two sub-components, namely the extent to which an individual has access to the means to exercise control over the target behavior, called the perceived control ability (control belief) and the situation-specific confidence of the individual to control the target behavior. Involved in behavior, labeled self-efficacy (selfefficacy)Although the use of indicators of self-efficacy (self-efficacy) and self-control beliefs (control belief) has not been identified empirically, that these two factors are correlated and reveal high internal consistency in explaining perceived control over behavior. 


\subsubsection{Personal Car Purchase Intention}

Purchase intention as a consumer's preference in buying a product. Intentions can be influenced by internal factors, external factors, and perceptions of behavioral control. As long as a person is really inhis selfcontrol, the actions taken can function as actual control and predict behavior. Research related to car purchase intentions primarily uses TPB as a theoretical basis.

\subsubsection{Relationship Between Variables}

Respondents with a more active lifestyle tend to have higher vehicle ownership. A socially active lifestyle that combines family activities with leisure time is associated with higher car ownership to support this lifestyle. The impact of car ownership is positively related to a person's higher travel rate. For example, the lifestyle of enjoying free time with family and trends with friends associated with social activities require more car availability. Regardless of the purpose of the trip, a person with a traveling lifestyle has a favorable preference for the car as the fastest mode of travel, cheapest, most convenient, and most suitable.

\subsubsection{Relationship between Traveling Lifestyle and Personal Car Purchase Intention}

The desire to buy a product can represent a person's lifestyle. An increase in a person's lifestyle will increase a person's purchase intention preference, followed by a purchase decision [9]. Like purchasing an iPhone brand smartphone, prioritizes current trends rather than function. Regarding the selection of ecolabel products also states that someone who cares about health, beauty, and appearance tends to influence their purchasing decisions for eco-label products.

\subsubsection{Relationship between Characteristics and Attitude of Car Ownership}

Gender, monthly income, and educational background affect the buying behavior of electric cars so that they are feasible to be included in the model. Likewise, research related to demography and the use of Computer Information Technology (ICT) concludes that three indicators in demography affect a person's attitude towards using ICT, namely income, computer time, and internet usage time. namely that a person's background can provide fundamental insights from beliefs even though it does not directly affect intentions or behavior.

\subsubsection{Relationship between Attitude of Car Ownership on Personal Car Purchase Intention}

Using the Theory of Planned Behavior, the use of attitude variables to measure a person's intentions has been widely studied before. In their research, attitude is the dominant variable in the intent to purchase a safer car. Likewise, concludes that attitude is an essential determinant in car ownership where the aspect of freedom posed by the vehicle is the main factor in purchasing.

\subsubsection{The Relationship between Subjective Norms and Personal Car Purchase Intentions}

The subjective norm is an individual's perception of how other people expect him to behave and encourages the individual to fulfill the expectations of others who are important to him. The most significant influence of hybrid car purchase intention in China is subjective norms based on collectivism and social pressure. The subjective norm variable weak influences attitudes towards car purchase intentions.

\subsubsection{Relationship between Behavioral Control and Personal Car Purchase Intention}

A person's belief in owning a car can be measured by the ability to maintain it and the availability of funds. Costs that arise outside of maintenance also play a role in determining someone's intention to buy a car. Car-oriented individuals are aware of the tax obligations that must be prepared and are more likely to use a car on every trip.

The fear of contracting COVID-19 triggers the intensity of the use of private vehicles as well as the intention to own a vehicle. Lifestyle changes in traveling, especially the choice of a private car, are also influenced by the primary destination and distance traveled during the pandemic. However, the economic pressure of the impact of the pandemic has become a firm perception control that holds back the realization of intention to make a personal vehicle purchase decision. Asurvey conducted by Ipsos, China's success in recovering new vehicle sales was driven by four factors: economic recovery, perceptions of security in using private vehicles, the desire to travel, and stimulus from the government. Intention to purchase a private car is also strongly influenced by attitude factors based on the Theory of Planned Behavior, followed by behavioral control and subjective norms.Meanwhile, The travel lifestyle has a close relationship with the level of car ownership. 


\subsection{Hypotheses}

Based on the theoretical relationships described above, several research hypotheses can be formulated as follows:

H1: Traveling lifestyle influences the attitude of private car ownership.

$\mathrm{H} 2$ : Individual characteristics affect the attitude of private car ownership.

H3: Traveling lifestyle affects the intention to purchase a private car during the pandemic.

H4: The attitude of owning a private car affects purchasing a personal vehicle during the pandemic.

H5: Subjective norms affect the intention to purchase a private car during the pandemic.

H6: Behavioral control affects the intention to purchase a private car during the pandemic.

\section{RESULT AND DISCUSSION}

The Covid-19 pandemic that has occurred since March 2020 in Indonesia has shifted people's behavior, including the travel lifestyle. Concerns about the transmission of the epidemic, the implementation of the Large-Scale Social Restriction (PSBB) policy, and the Enforcement of Community Activity Restrictions (PPKM) have increasedpeople's intention to travel using private cars instead of public transportation.

The survey in the field said that the increasing intention of people to use private cars also increased people's choices to buy personal vehicles to facilitate mobility and reduce the risk of transmission while traveling. The need for private vehicle results from the threat of information and the type of work or the fulfillment of daily requirements for activities outside the home.However, the intention to own is not directly proportional to realizing new car sales in 2020. This is due to the economic pressure due to the pandemic, which has impacted the declining purchasing power of consumers.

The intention to buy a private car could be explained through the Theory of Planned Behavior with variables of attitude towards private car ownership, subjective norms, and behavioral control that a person's perspective is motivated by the characteristics of that person. So this study will use individual attributes to see their effect on car ownership attitudes. The use of lifestyle variables that directly affect intentions.Based on the thoughts above, this research can be described with the following framework:

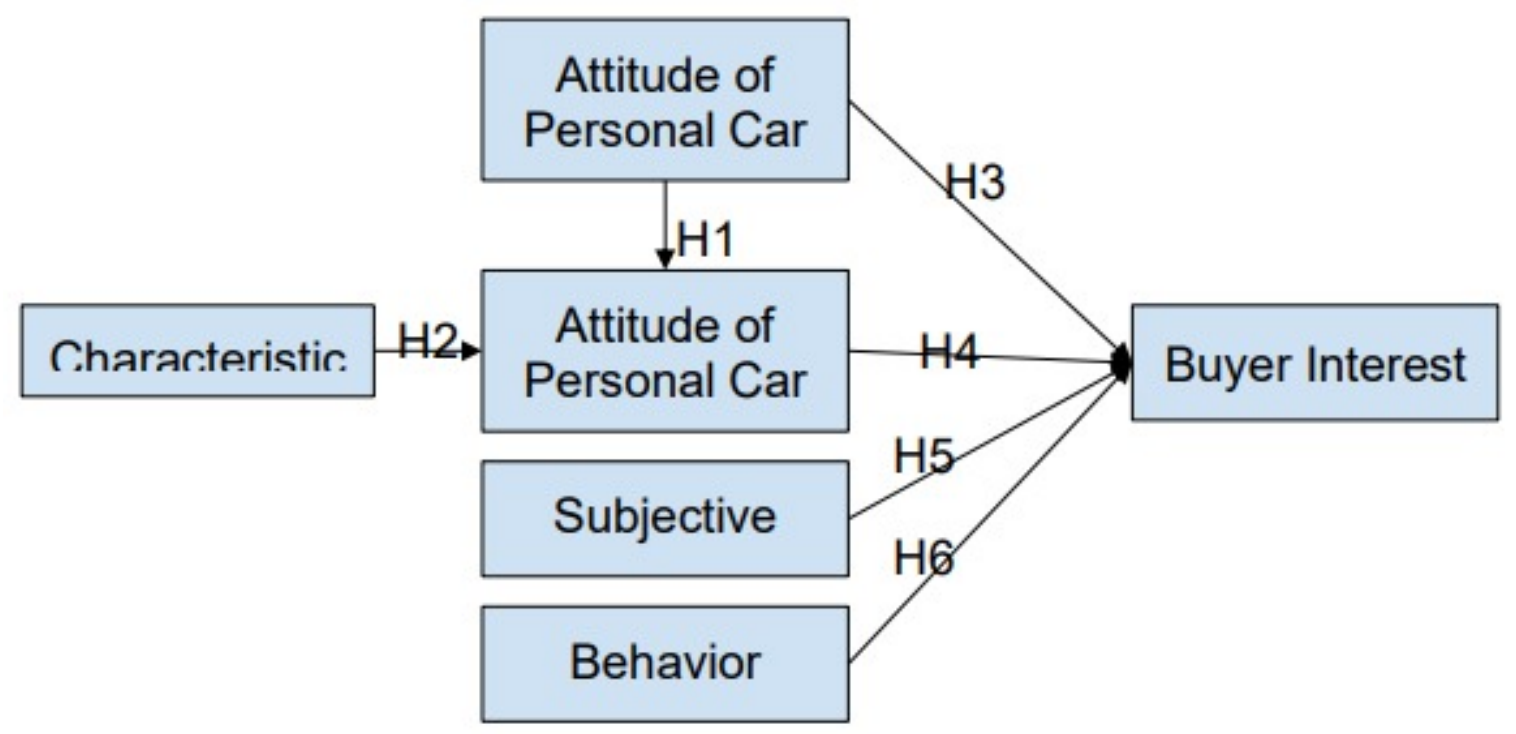

Figure 7. Thinking Framework

\subsection{Problem}

The fear of contracting COVID-19 triggers the intensity of the use of private vehicles as well as the intention to own a vehicle. Lifestyle changes in traveling, especially the choice of a private car, are also influenced by the primary destination and distance traveled during the pandemic. However, the economic pressure of the impact of the pandemic has become a firm perception control that holds back the realization of intention to make a personal vehicle purchase decision. Asurvey conducted by Ipsos, China's success in 
recovering new vehicle sales was driven by four factors: economic recovery, perceptions of security in using private vehicles, the desire to travel, and stimulus from the government. Intention to purchase a private car is also strongly influenced by attitude factors based on the Theory of Planned Behavior, followed by behavioral control and subjective norms.Meanwhile, The travellifestyle has a close relationship with the level of car ownership.

\section{CONCLUSION}

The results of this study are expected to provide benefits, both practical and theoretical, namely:

1. By knowing the character of consumers who intend to buy private cars during the pandemic, the automotive industry can design marketing strategies that are right on target or determine the right segments.

2. For the government, that is input in formulating policies to support the automotive industry.

3. Theoretical benefits are for readers, as learning materials and new insights about the factors that influence consumer behavior.

\section{REFERENCES}

[1] A.Al Anbariyyah and A. Wardhana, "Analisis Faktor Citra Merek Produk Wuling Motors Indonesia," eProceedings Manag., vol. 7, no. 3, 2020.

[2] M. R. Fatmi, “COVID-19 impact on urban mobility,” J. Urban Manag., vol. 9, no. 3, pp. 270-275, 2020.

[3] B. P. Statistik, “Analisis hasil survei dampak covid-19 terhadap pelaku usaha," BP Indones. Anal. Has. Survei Dampak Covid-19 terhadap Pelaku Usaha, vol. 5, 2020.

[4] L. G. Schiffman and J. Wisenblit, "Consumer Behavior, 12th Global Edition." United Kingdom. Pearson Education Limited, 2019.

[5] S. Shakibaei, G. C. De Jong, P. Alpkökin, and T. H. Rashidi, "Impact of the COVID-19 pandemic on travel behavior in Istanbul: A panel data analysis,” Sustain. cities Soc., vol. 65, p. 102619, 2021.

[6] M. Chinazzi etal., "The effect of travel restrictions on the spread of the 2019 novel coronavirus (COVID19) outbreak," Science (80-. )., vol. 368, no. 6489, pp. 395-400, 2020.

[7] D. M. Martanti, F. Magdalena, N. P. D. Ariska, N. Setiyawati, and W. C. B. Rumboirusi, "Dampak Pandemi Covid-19 terhadap Tenaga Kerja Formal di Indonesia,” Populasi, vol. 28, no.2, pp. 52-69.

[8] K. A. A. Kassim, L. Arokiasamy, and C. H. Ping, "Intention to Purchase Safer Car in Indonesia: An Application of Theory of Planned Behaviour.," Glob. Bus. Manag. Res., vol. 11, no. 1, 2019.

[9] S. Amri and D. Prihandono, "Influence lifestyle, consumer ethnocentrism, product quality on purchase decision through purchase intention,” Manag. Anal. J., vol. 8, no. 1, pp. 25-38, 2019.

[10] M. J. Beck, D. A. Hensher, and E. Wei, "Slowly coming out of COVID-19 restrictions in Australia: Implications for working from home and commuting trips by car and public transport," J. Transp. Geogr., vol. 88 , p. 102846, 2020.

[11] M. Abdullah, C. Dias, D. Muley, and M. Shahin, "Exploring the impacts of COVID-19 on travel behavior and mode preferences," Transp. Res. Interdiscip. Perspect., vol. 8, p. 100255, 2020.

[12] I. Priyayi, "The Influence of Lifestyle, Attitude of Consumer, and Marketing Mix on Purchase Decision of Eco-Label Cosmetic Products in Indonesia and Malaysia.” Bogor Agricultural University (IPB).

[13] P. S. Peixoto, D. Marcondes, C. Peixoto, and S. M. Oliva, "Modeling future spread of infections via mobile geolocation data and population dynamics. An application to COVID-19 in Brazil," PLoS One, vol. 15 , no. 7 , p. e0235732, 2020. 
[14] M. Z. Irawan, M. Rizki, T. B. Joewono, and P. F. Belgiawan, "Exploring the intention of out-of-home activities participation during new normal conditions in Indonesian cities,'Transp. Res. Interdiscip. Perspect., vol. 8, p. 100237, 2020.

[15] E. Guustaaf, U. Rahardja, Q. Aini, H. W. Maharani, and N. A. Santoso, "Blockchain-based Education Project," Aptisi Trans. Manag., vol. 5, no. 1, pp. 46-61, 2021.

[16] N. Lutfiani, U. Rahardja, and K. T. Khasanah, "The Development Viewboard As an Information Media at Official Site Asosiation,” APTISI Trans. Manag., vol. 6, no. 1, pp. 10-18, 2022.

[17] M. A. Mumen, F. P. Oganda, N. Lutfiani, and I. Handayani, "Implementation of OJS Based iJC Media E-Journal System at University of Pramita Indonesia," Aptisi Trans. Manag., vol. 4, no. 2, pp. 168-177, 2020 .

[18] U. Rahardja, Q. Aini, F. Budiarty, M. Yusup, and A. Alwiyah, "Socio-economic impact of Blockchain utilization on Digital certificates,"Aptisi Trans. Manag., vol. 5, no. 2, pp. 106-111, 2021.

[19] U. Rahardja, Q. Aini, and A.Khoirunisa, "Effect of iDu (iLearning Education) on Lecturer Performance in the Lecture Process," Aptisi Trans. Manag., vol. 2, no. 2, pp. 140-148, 2018.

[20] Q. Aini, N. Lutfiani, N. P. L. Santoso, S. Sulistiawati, and E. Astriyani, "Blockchain For Education Purpose: Essential Topology,” Aptisi Trans. Manag., vol. 5, no. 2, pp. 112-120, 2021.

[21] U. Rahardja, F. Andriyani, and T. Triyono, "Model Scheduling Optimization Workforce Management Marketing,” Aptisi Trans. Manag., vol. 4, no. 2, pp. 92-100, 2020.

[22] U. Rahardja, N. Lutfiani, and H. L. Juniar, "Scientific Publication Management Transformation In Disruption Era,” Aptisi Trans. Manag., vol. 3, no. 2, pp. 109-118, 2019.

[23] F. Agustin, Q. Aini, A. Khoirunisa, and E. A. Nabila, "Utilization of Blockchain Technology for Management E-Certificate Open Journal System,” Aptisi Trans. Manag., vol. 4, no. 2, pp. 133-138, 2020.

[24] Q. Aini, I. Dhaniarti, and A. Khoirunisa, "Effects of ilearning media on student learning motivation," Aptisi Trans. Manag., vol. 3, no. 1, pp. 1-12, 2019.

[25] Q. Aini, A. Alwiyah, and D. M. Putri, "Effectiveness of Installment Payment Management Using Recurring Scheduling to Cashier Performance,” Aptisi Trans. Manag., vol. 3, no. 1, pp. 13-21, 2019.

[26] A. C. Purnomo, B. Pramono, and F. P. Oganda, "Design of Information System in Admission of New Students Based on Web in SMK Al Amanah," Aptisi Trans. Manag., vol. 3, no. 2, pp. 159-167, 2019.

[27] S. Sudaryono, U. Rahardja, and D. Apriani, "The CICES Journal Governance Performance Improvement on Quality of Current Issues (Case Study of STMIK RAHARJA)," Aptisi Trans. Manag., vol. 3, no. 1, pp. 57-64, 2019.

[28] F. Sutisna and T. Handra, "The Theory of Planned Behavior Influences Online Shopping Behavior," APTISI Trans. Manag., vol. 6, no. 1, pp. 52-61, 2022.

[29] P. Hendriyati, F. Agustin, U. Rahardja, and T. Ramadhan, "Management Information Systems on Integrated Student and Lecturer Data,” APTISI Trans. Manag., vol. 6, no. 1, pp. 1-9, 2022.

[30] U. Rahardja, N. Lutfiani, and S. Amelia, "Creative Content Marketing In Scientific Publication Management In Industrial Era 4.0," Aptisi Trans. Manag., vol. 3, no. 2, pp. 168-177, 2019.Powered by TCPDF (www.tcpdf.org) 